\title{
Pauci-immune proliferative glomerulonephritis and fungal endocarditis: More than a mere coincidence?
}

\author{
Hussain Aboud, ${ }^{1}$ Harini Bejjanki, ${ }^{2}$ William L Clapp, ${ }^{3}$ Abhilash Koratala ${ }^{4}$
}

'Pulmonary, Critical Care and Sleep Medicine, Yale University School of Medicine, New Haven, Arizona, USA

${ }^{2}$ Nephrology, Hypertension and Renal Transplantation, University of Florida, Gainesville, Florida, USA

${ }^{3}$ Pathology, Immunology and Laboratory Medicine, University of Florida, Gainesville, Florida, USA

${ }^{4}$ Medicine/Nephrology, University of Florida, Gainesville, Florida, USA

\section{Correspondence to}

Dr Harini Bejjanki,

harini.bejjanki@medicine.ufl.edu

Accepted 12 February 2019

\section{DESCRIPTION}

Glomerulonephritis (GN) due to infective (primarily bacterial) endocarditis is well documented with the most common lesions being necrotising and crescentic GN, followed by endocapillary proliferative GN. Prominent C3 staining and subepithelial immune deposits on electron microscopy are commonly associated with infection-related GN than pauci-immune picture of antineutrophil cytoplasmic antibody (ANCA) associated vasculitis. ${ }^{1}$ Here we present a case of pauci-immune proliferative $\mathrm{GN}$ in a patient with fungal endocarditis.

A 52-year-old white man with a history of intravenous drug abuse, chronic hepatitis $\mathrm{C}$ and diabetes mellitus initially presented to our institution with fever and bilateral lower extremity rash/palpable purpura (figure 1A). Serum creatinine was within normal limits at presentation. Biopsy of the rash demonstrated leucocytoclastic vasculitis with neutrophil predominance. He was also found to have native aortic valve endocarditis with $\sim 1.5 \mathrm{~cm}$ vegetation and Candida parapsilosis fungaemia which failed treatment with Micafungin and therefore switched to amphotericin B and flucytosine. There were no other lesions characteristic of Infective Endocarditis such as Osler's nodes or Janeway lesions. Later, he developed worsening renal function with sub-nephrotic proteinuria and work up revealed dysmorphic RBCs in the urine, hypocomplementaemia with low C3 of 41(87$200 \mathrm{mg} / \mathrm{dL})$, low $\mathrm{C} 4$ of $<8(13-50, \mathrm{mg} / \mathrm{dL})$, positive C-ANCA, proteinase 3 (PR3) and cryoglobulins.

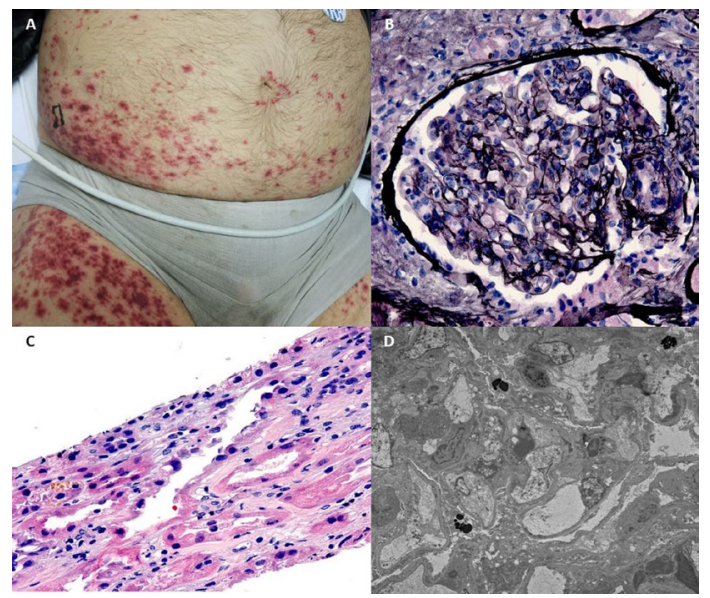

Figure 1 (A) Purpuric rash on the abdomen and lower extremities. Renal biopsy demonstrating (B) mesangial and endocapillary hyperplasia (silver stain); (C) acute tubular injury (H\&E stain); (D) electron microscopy demonstrating glomerular hypercellularity without any deposits.
Serum immunofixation revealed a small M-spike of $0.7 \mathrm{~g} / \mathrm{dL}$ which was attributed to possible smouldering myeloma based on the bone marrow biopsy finding of $15 \%$ plasma cells. M-spike or band can also be found in the context of fungal infection and it is considered among the classification criteria for cryoglobulinaemic vasculitis attributed to $\mathrm{HCV}$ infection,. ${ }^{2}$ Testing for rheumatoid factor was negative. In the presence of multiple confounding factors and varied differentials (eg hepatitis C-associated membranoproliferative GN, postinfectious $\mathrm{GN}$ and ANCA vasculitis), a renal biopsy was obtained which showed proliferative GN with acute tubular necrosis (figure 1B-D). There were no glomerular crescents and immunofluorescence was negative except for trace IgM. His renal function worsened requiring initiation of haemodialysis. Immunosuppressive therapy was not attempted because of active fungaemia. While the hepatitis $\mathrm{C}$ antibody test was positive viral load (Hepatitis C RNA-PCR) was negative on multiple occasions.

Interestingly, ANCA antibody is found in up to $28 \%$ of the tested patients with infective endocarditis in one study. ${ }^{3}$ Two other retrospective studies showed similar findings of $24 \%,{ }^{4}$ and $33 \% .^{5}$ On the other hand, ANCA-positive postinfectious pauci-immune GN in association with Candida parapsilosis has never been reported in the literature to the best of our knowledge. However, there has been a report of ANCA-negative pauci-immune crescentic GN associated with this fungus which responded to anti-fungal therapy and corticosteroids, ${ }^{6}$ It is likely that the fungal capsular polysaccharide triggers inflammation with or without activation of complement cascade. ${ }^{7}$ Whether ANCA antibody was a coexistent distinct entity or induced by fungal infection or underlying hepatitis $\mathrm{C}$ in our patient remains elusive.

\section{Patient's perspective}

Patient passed away soon after he left the Hospital against medical advise. Patient's mother recollected how the patient was excellent at what he did. 'He would bring old radios home and make them work'. She shared how 'he was hospitalised, and they could not fix it', 'dialysis did not seem to work'. 'The infection in his foot, went up to his heart, his kidneys and up into the brain and that was it'. "All the while they were testing, he was optimistic. I guess these infections are really bad, because they let loose and go to other organs and then it's a done deal'. 


\section{Learning points}

- Antineutrophil cytoplasmic antibody (ANCA) antibody is found in a considerable proportion of patients with infective endocarditis. Whether ANCA antibody is a coexistent distinct entity or induced by the underlying infection needs further investigation.

- Post-infectious pauci-immune glomerulonephritis, although uncommon can be seen in association with Candida parapsilosis infective endocarditis.

Contributors HA: Drafted the initial version of the manuscript, participated in patient care. HB: Drafted the final version of the manuscript, primary Attending physician on the case, coordinated patient care. WLC: Pathologist on the case, provided pathology images and pertinent input. AK: Attending physician on the case, reviewed and revised the manuscript for critical intellectual content.

Funding The authors have not declared a specific grant for this research from any funding agency in the public, commercial or not-for-profit sectors.
Competing interests None declared.

Patient consent for publication Not required.

Provenance and peer review Not commissioned; externally peer reviewed.

\section{REFERENCES}

1 Hilhorst M, van Paassen $\mathrm{P}$, van Rie $\mathrm{H}$, et al. Complement in ANCA-associated glomerulonephritis. Nephrol Dial Transplant 2017;32:1302-13.

2 Quartuccio L, Isola M, Corazza L, et al. Validation of the classification criteria for cryoglobulinaemic vasculitis. Rheumatology 2014;53:2209-13.

3 Boils CL, Nasr SH, Walker PD, et al. Update on endocarditis-associated glomerulonephritis. Kidney Int 2015:87:1241-9.

4 Langlois V, Lesourd A, Girszyn N, et al. Antineutrophil cytoplasmic antibodies associated with infective endocarditis. Medicine 2016;95:e2564.

5 Ying $\mathrm{CM}$, Yao DT, Ding HH, et al. Infective endocarditis with antineutrophil cytoplasmic antibody: report of 13 cases and literature review. PLoS One 2014:9:e89777.

6 Scemla A, Charlier C, Noel LH, et al. Pauci-immune crescentic glomerulonephritis without ANCA in a patient presenting with Candida parapsilosis endocarditis. Med Mal Infect 2016:46:163-5

7 Snarr BD, Qureshi ST, Sheppard DC. Immune recognition of fungal polysaccharides. J Fungi 2017;3:47.

Copyright 2019 BMJ Publishing Group. All rights reserved. For permission to reuse any of this content visit

https://www.bmj.com/company/products-services/rights-and-licensing/permissions/

BMJ Case Report Fellows may re-use this article for personal use and teaching without any further permission.

Become a Fellow of BMJ Case Reports today and you can:

- Submit as many cases as you like

- Enjoy fast sympathetic peer review and rapid publication of accepted articles

- Access all the published articles

Re-use any of the published material for personal use and teaching without further permission

For information on Institutional Fellowships contact consortiasales@bmjgroup.com

Visit casereports.bmj.com for more articles like this and to become a Fellow 